\title{
ALTERAÇÃO HIDROTERMAL E MINERALIZAÇÃO DE METAIS RAROS (Sn, Nb, Ta) DO MACIÇO CARITIANAS - RONDÔNIA
}

O.G.de Pinho ${ }^{1}$

J.S.Bettencourt ${ }^{2}$

No Maciço Caritianas (Fig. 1), as seguintes facies magmáticas graníticas foram descritas: a - granito equigranular $(\gamma \mathrm{em})$ destacando-se os sub-tipos $\left(\gamma \mathrm{em}{ }_{1}\right)$ e $\left(\gamma \mathrm{em}_{2}\right)$ que são variações do tipo principal $(\gamma \mathrm{em}), \mathrm{b}$ - granito heterogranular $(\gamma \mathrm{h}), \mathrm{c}$ - granito porfirírito ( $\gamma$ epf) e suas variedades dos tipos $(\gamma \mathrm{pfm})$ e $\left(\gamma \mathrm{pfm}_{1}\right)$ e d - microgranito $(\gamma \mathrm{mg})$ além de corpos filonianos pegmatíticos associados.

Trata-se de granitos "subsolvus" com predominância de biotita granitos que se posicionam no campo 3a. (sienogranitos), enquanto que as variedades mais afetadas por fenômenos metassomáticos situam-se no campo dos álcali-feldspato granitos do diagrama QAP de Streckeisen.

O exame das feições texturais relacionadas a mineralizações estaníferas dos granitos do Maciço Caritianas sugere que as rochas foram submetidas a processos de alteração hidrotermal pós-magmática dos tipos pervasivo e local fissural. Os principais tipos de transformações metassomáticas pós-magmáticas são representadas por: 1 - alteração pervasiva intersticial (metassomatismos sódico e potássico), 2 - alteração fissural (metassomatismo ácido $\mathrm{H}^{+}$), 3 - metassomatismo silícico, $\mathrm{Si}^{+}$e 4 - alteração argílica.

Metassomatismo Potássico $\left(\mathrm{K}^{+}\right)$- a feição predominante resulta da substituição de plagioclásio por microlina secundária. À baixa temperatura reconhece-se que cristais de feldspato potássico se reordenam e forma-se microclina límpida exibindo geminação em grade.

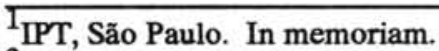

${ }^{2}$ Departamento de Geologia Econômica e Geofísica Aplicada, Instituto de Geociências/USP, São Paulo e Unesp, SP.
} 
Metassomatismo Sódico $\left(\mathrm{Na}^{+}\right)$- caracteriza-se por diferentes tipos texturais de albita $(A n<5)$, bem como notável descalcificação primária de plagioclásio. Columbitatantalita, monazita e zircão podem ser minerais de minério acompanhantes.

Os fluidos responsáveis por esse metassomatismo são caracterizados, comumente, por Th ente 400 e $600^{\circ} \mathrm{C}$ e salinidade, mais magmática, variável entre $2-30 \%$ eq. $\mathrm{NaCl}$.

Metassomatismo Ácido $\left(\mathrm{H}^{+}\right)$- ao nível de erosão atual do maciço a greisenização, como processo dominante, é restrita a veios de preenchimento de fissuras. Quartzo, protholitionita, zinwaldita, muscovita, topázio, clorita, cassiterita, rutilo, ilmenita, hematita e pirita são os minerais principais dos greisens.

Os estudos de inclusões fluidas efetuados nos greisens do maciço revelaram Th variáveis entre 20 a $550^{\circ} \mathrm{C}$ e valores de salinidade baixa a moderada entre 6 a $24 \%$ eq. $\mathrm{NaCl}$.

Metassomatismo Silícico $\left(\mathrm{Si}^{+}\right)$- é representado por veios de quartzo que cortam tanto granitos quanto greisens, associados ou não à alteração hidrotermal de paredes (sericitização, cloritização e muscovitização) ou franjas de mica branca (sericita).

Há várias gerações de veios cujos principais minerais são: quartzo, fluorita, carbonato de manganês, pirita, minerais de argila, siderita, óxido-hidróxidos de ferro e manganês e epidoto.

Duas populações de inclusões fluidas, já estudadas, indicaram para o primeiro grupo Th entre $200-250^{\circ} \mathrm{C}$ e salinidade baixa 0 a $5 \%$ eq. $\mathrm{NaCl}$ enquanto que para o segundo grupo obtiveram-se Th entre $90-150^{\circ} \mathrm{C}$ e salinidade muito variável entre $10-23 \%$ eq. $\mathrm{NaCl}$.

Alteração Argílica - corresponde ao estádio final da evolução fluidal, sendo caracterizada por desenvolvimento incipiente de minerais argilosos em feldspatos e micas a Th dos fluidos abaixo de $200^{\circ} \mathrm{C}$. 

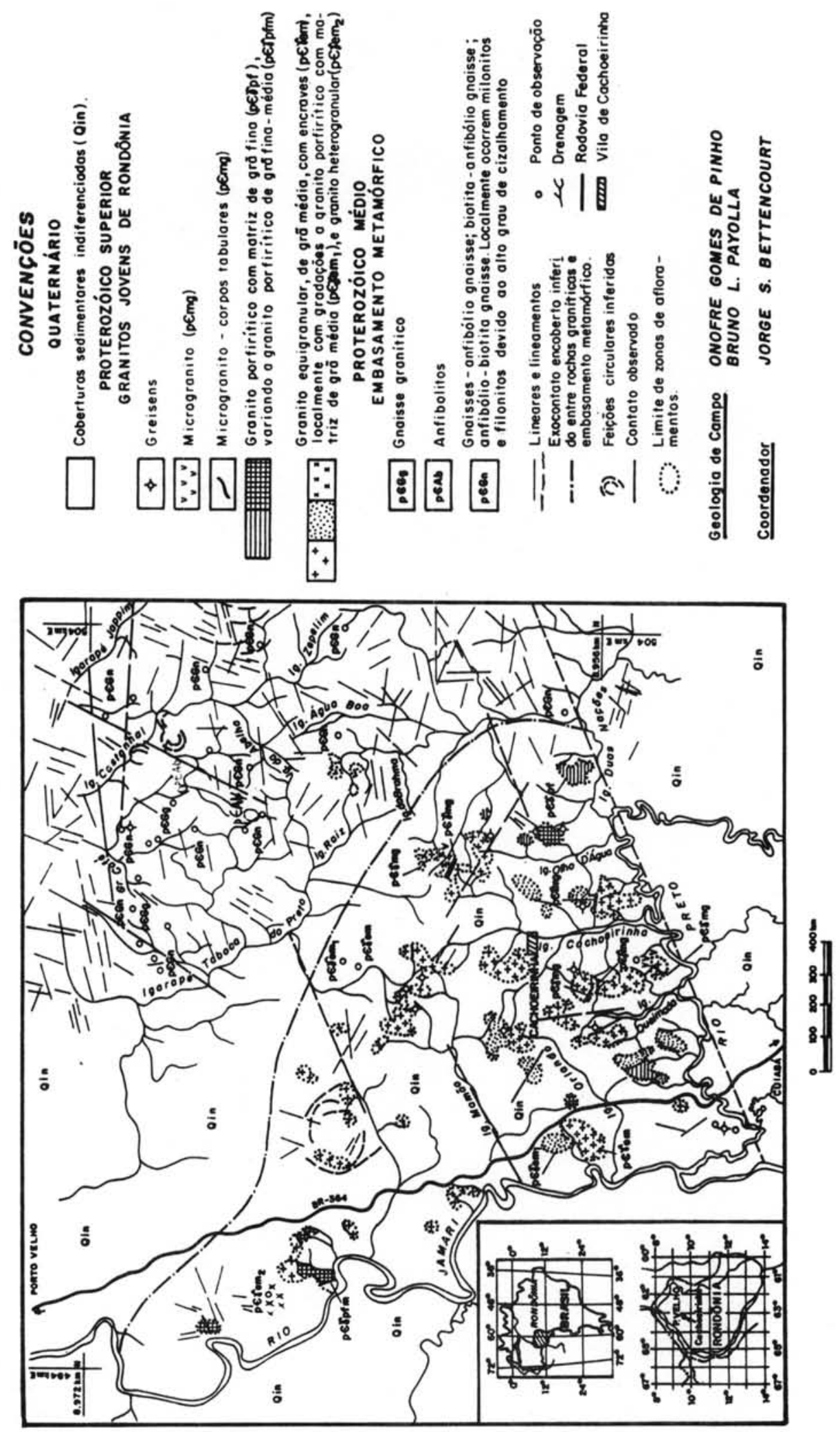